UDC $81 ; 81 ' 42 ; 801.7$

DOI https://doi.org/10.32838/2663-6069/2020.3-2/04

Hajiyeva $M$.

Azerbaijan University of Languages

\title{
COGNITIVE SYSTEM AND COMPUTER ANALOGY
}

When you look attentively at the structure and activity of modern computers, at first glance it resembles the human organism. Each of them is literally programmed to execute special commands. This similarity can be observed more in the human cognitive system. It is known from the conducted research that the cognitive system belonging to each healthy person is organized from modules with different executive properties. Each module is independent in its field of activity. But here, inter-module communication is considered particularly important. Complex human behavior is considered possible precisely because of these connections. Language that reflects in a certain sense the signs of thought is considered the most effective tool in this direction. In this regard, scientists trying to define the human cognitive system through language have come together in the framework of cognitive linguistics. Collaboration between language and thought modules is the most obvious indicator of inter-module communication. And in what situation these connections are realized, despite numerous studies, they are still considered dark for humanity. Language is algorithmically considered an innate competence with unique abilities that perform processes. Khomsky was a big push to expand these studies. The concept of universal grammar, organized from six systems put forward by the scientist on the basis of the N. Khomsky tradition in his research, aroused particular interest in the framework of modular research. A scientist named Fodor introduced a popular modular concept to cognitive architecture. The modularity principle, which has become part of the terminology of cognitive linguistics, is one of the main elements of the brain's infrastructure. Here, each pre-programmed subsystem shapes human behavior in interaction with other subsystems. In this model, which resembles the computer system of J. Fodor, the process of language perception and understanding is perceived as a modular process, and the end result is perceived as a central processor. In this infrastructure, thinking is also based on algorithmic rules according to its subsystem. Supporting the connection between the theory of consciousness and evolution, unlike J. Fodor, S. Pinker considers the work of consciousness as a real computer system. In this regard, the article compares the opinions of scientists who approach the modular theory of the brain with various aspects, and draws interesting ideas to the analysis. Although the claims put forward by various researchers sometimes do not reach theoretical evidence, in a certain sense they cause a number of interesting studies.

Key words: cognitive system, memory, universal grammar, brain modularity, neuron, mental dictionary, mental grammar, left and the right hemispheres.

Introduction. Along with "modular" linguistics, which has recently been considered one of the topics chosen for its relevance, these are problems of interest to other Sciences. To investigate activities related to a modular system, it is necessary to consider a computer system that existed before cognitive theory. As you know, before 1980, the theory of cognition was originally described on a computer figuratively. This was formed as computing devices adapted to the human-computer analogy. The operating system written to the computer's memory is previously placed on the computer's hard disk as a batch program and plays an active role in the implementation of each work done in the future. During the great computer revolution, computing devices created using the Turing machine scheme in 1947 were called von Neumann computers in honor of the American-
Hungarian mathematician and logician John von Neumann. After a certain period of time, conditions were created for development of several processor computers working simultaneously to increase the speed of information processing and obtain more accurate results. This type of computer was named "non von-Neuman". The main problem in their work was the creation of connections between individual microprocessors. The development of computer generations in this direction has aroused particular interest in the study of the human brain in this ampoule. As a result, a number of interesting research papers appeared.

Discussion. The center of the human cognitive system consists of a processor and modules, such as in electronic computers. Each module has an autonomous area, such as in computer operations, 
within the information contained in it, and performs special functions. For the first time, the American neuroinformatic David Marr introduced the term "module" in science to use the description of psychological processes. [20, p. 483-524] D. Marr presented "The principle of modular organization" as parts that do not depend on each other, but serve a common task. Thus, interesting research on improving computer activity, which resembles the mechanism of the brain, gave an impetus to the study of moments related to cognition. "Cognitive linguistics studies the complex relationship between language and thinking" [10]. From this point of view, issues such as the development of a computer model in accordance with human intelligence, the architecture of information storage in human memory, and universal problem solving have led to a number of cognitive transformations. N.Khomsky's views, which has its own place in this scientific turn on both maternal ability and "domain-specific" were further actualized in his research in this area [4]. From the central figures of generative linguistics, N. Khomsky and his followers claim that a person has innate symbolic rules, unique abilities that perform processes algorithmically, and these excellent skills are the functional base that serves to perform various modules. According to the statements of generativistsfollowers of this sect, the existence of a "spoken organ" arises on the basis of symbolic rules, thanks to language algorithms for the formation of ontogenesis [21, p. 707-784]. The partners who put forward such a mechanism do not accept the emergence of another form of the language. For example, N. Khomsky called this mechanism a "grammatical explosion" resulting from macromutation, while S. Pinker considers it as a result of natural selection of small mutations. In psychology, neobehaviorists and connexionists in linguistics consider this mechanism as a language teaching procedure based on the work of assosiative memory [18]. Analyzing any approach to language and its existence, it is impossible to deny its close cooperation with memory. Memory in each direction plays a fundamental role in the types of behaviors associated with the brain, and is a research center that has not yet found a solution with its complex structure. It also has different types and different functions. For example, A. Baddeley proposed the concept of "working memory". According to the researcher, "short-term memory is not the only type of temporary memory. It is designed to store information that is not too large for a few seconds before it goes into long-term memory... the capacity and function of working memory is wider than short-term memory, and actually provides the current activity and intelligence of a person" $[14 ; 36]$.

"Working memory" is generally regulated by the operation of associative memory. According to the generativists, associative memory is an associative approach to linguistic reality and the neural network, perceived as a form of language ability that has changed over time. E.Tulving explains associative memory in different ways. In his opinion, longterm memory is organized in two different types, such as semantic and episodic memory. "Purposeful storage of information is associated with the work of semantic memory... and episodic memory stores the information received during the event, establishing connections between them. (for example, meeting someone for the first time). It provides a memory of events, people, and land that we encounter in the past. Episodic memory focuses on the individual and their feelings" [14, p. 36].

On the one hand, memory activity, on the other hand, cognitive structures are the main definitions that determine the structure of language. And language, which performs a number of important functions within society, is itself regulated in accordance with this mechanism. According to the results of research on brain functions that determine the activity of neurons in the process of intellectual activity, this activity involves not the entire brain, but only some areas responsible for language procedures. But how does this mechanism behave? If language is innate and has a specific area defined for language, is this area neurophysiologically isolated from other cognitive functions during behavior? Such questions have become the central point of research in research work based on the modularity principle.

Indeed, its modular concept, like the brain mechanism, is also a unique system created perfectly. In this system, special attention is paid to modules with a Preface, language, and thinking, as well as the interaction between them. This concept, which we begin to understand in detail, can reveal a number of points related to the negotiation activity. In this regard, the study of the brain mechanism is considered relevant research for linguistics and in particular neurodegeneration, psychedelics. With special ideas in this area, N. Khomsky considers universal grammar to be a genetic program consisting of six pre-programmed systems for human language. And subsystems show themselves here as a set of modules. The genetic program begins to form so that each person gets into the womb of the mother, inherent in the DNA. In accordance with this innate principle ".. some aspects of our knowledge and understanding 
are innate, according to genetic traits, although other elements of our nature are not wings, like the development of arms and legs, they are also considered part of biological genes" [15, p. 134]. So, in short, if we didn't have another innate structure, we wouldn't have language abilities. N. Khomsky, based on these biological genes and the general structure of people's identity, similar to the rules of mental activity, put forward another interesting idea that shocks the world. According to this statement, there is a common grammatical structure for all languages of the world. He called the term "universal grammar" a general "system of principles and rules" that forms the basis or features of all human languages. "The system of principles and rules inherent in all languages is formed not logically, but biologically" $[15$, p. 141$]$. Innate, this system that exists in every person is irreplaceable for all people. Biologically, this set of rules is determined when learning any new language. But being a supporter of mentalism, $\mathrm{N}$. Khomsky did not pay much attention to his reasoning.

Later, in 1983, a continuer of Khomsky, J.Fodor, a prominent American linguist and philosopher, followed the way of Khomsky, but was guided by Descartes "ideas in his book "Modularity of the Brain": "The idea of the Descartes doctrine is with us again, and this theory is a theory about the structuring of thought within "organs" $[17 ; 3]$. J.Fodor introduced a new approach to cognitive architecture and called it a modular concept [17]. Module is one of the main definitions of cognitivism. Most of the modules that Khomsky calls subsystems make up the complete infrastructure of the brain. Each simple, preprogrammed subsystem manages human behavior by entering into conflicting relationships. With these ideas, he laid the Foundation for a computer model of the brain that resembles a computer system in the mechanism of functioning, the process of persepsy and understanding of language refers to a modular process, and the end result-to the Central processor. According to the Fodor principle, thought processes function thanks to strictly organized algorithms. In the work of N. Khomsky, there are also ideas about this. But the approaches of J. Fodor and S. Pinker that he demonstrates in this area attract particular attention with their different positions. J. Fodor, contrary to the description of cognitive scientists, characterizes the theory of modularity as 3-division. For this reason, the human sense organs consist of receptors that respond to external stimuli. The information received from there is created in the form of neural codes. These codes are then transmitted and processed through the access module system. The result of processing is transmitted to the Central processor of the high cognitive process at the last moment. More specifically, it is triple the membership was organized by combining three independent from each other modules:

- access system- an area connected to our senses;

- transmitters- a representative system that converts our senses into the necessary codes;

- the Central nervous system - is the main space where mental actions take place.

Because of this membership, there is not much difference between perceptual processes and Central cognitive processes. Sensors (receivers) act as an interface between symbolic processes and the world. It is located on the border of the world and consciousness. The input pulse of the sensor is physical energy, and the output pulse is symbols. The access system or modules are specialized in specific areas. For example, although there is no separate unified system for vision, a separate system is available for customization color, shape, human face, etc. J. Fodor believes that each receiving mechanism is aimed at a specific type of stimulus. If it is directed to perform any task, then this work will be performed. Like the special algorithms of a computer program, the mechanism was created only for predefined operation. According to J. Fodor, input systems differ by specialty and are innate, whether they are autonomous or connected to a local, private, and structured neural system. According to the scientist, the human cognitive system is organized from a Central processor and modules. Each module is independent and runs in the information space it belongs to. They don't take into account information related to other modules when eating instead of tasks. That is, they do not use the information contained in the Central processing units, and the Central processing units have limited access to mental representation. In this respect, modular processors differ from Central processing units. If modular processors have an encapsulation system, then Central processors, on the contrary, are connected to the entire information system. Central processing units work exclusively for General information processing. For example, we can close our eyes and guess what an item is that has been delivered to us. This is determined by the visual module of our Central processor. Even with a limited amount of information transmitted, we can achieve certain results based on our closed eyelids, from our common world meeting. Fodor calls it, the phenomenon is isotropic. Here persepsi pre-adapted to the shared reality of the world. 
According to J.Fodor's notes, all this activity is based on the language of thought. The language of thought is a unique metaphor. It cannot be identified in either natural or artificial language. In terms of the elements and units that it owns, it differs from regular language elements. According to L. S. Vygotsky, "the very movement of thought activity from thought to word is development. Opinion is not expressed in words, it is supplemented by words." [5, p. 469] This language is the founder of every process in consciousness. The transformation and interpretation that takes place on the basis of Triple membership is carried out through this language of thought. The input system uses some physical energy, which is converted into a stack of characters, entering the central processor. Words heard by a human, heat is transferred from the linguistic expressions in a language of thought, language elements of the rethinking translated into a language known to man after the occurrence of a mechanism of mutual exchange.

Considering the activity of consciousness as the interaction of three Autonomous modules, J. Fodor supports the idea that each of them is based on the theory of the evolution of consciousness. Therefore, consciousness is a system in which the mystery has not yet been solved. These views of J. Fodor drew criticism from neo-Darwinist S. Pinker. Unlike J. Fodor, according to S. Pinker, language is not an element of culture at all, it is perceived as one of the biological elements in the construction of our brain [9, p. 67-69]. S. Pinker perceives the work of consciousness as a real computer system. (i.e., similar to a computer). The processor here also has a bunch of normal reflexes, which allows you to carry out smart activities in the brain. S. Pinker explains this with an interesting example: all humans are mortal. Socrates is a human. As a result, Socrates is also mortal. In his opinion, there are probably three groups of neurons in the brain. Each neural in group I means a person in general. Neurons located in group II are responsible for the logical compatibility of the expression. And group III neurons represent class concepts. As a result of the interaction of these groups, a person comes to a final opinion. According to S. Pinker, this principle is very simple in terms of structure: that is, a mental dictionary+mental grammar. And he explains mental grammar as grammatical genes, elements "formed as a result of DNA, in certain parts of the brain, which encode and transcribe proteins for a certain time" [9, p. 306].

One of the researchers who definitely do not accept J. Fodor's modular theory is M. Cole.
According to M. Coula, the information is first received by the modular system, then filtered in the cultural model Assembly and processed in the central processor. Here, "cultural connections" combine modules and synthesize contexts that suit them. At the last moment, the central processor receives culturally processed information [6, p. 226]. According to M. Cole, the parent module system is programmed for cultural processing of information. In addition to the theory given by J. Fodor, M. Cole highlights the cultural context. Each information entering the input system is filtered and processed by the person's cultural context filter, and then inserted into the central processor. In Fodor's theory, which has gained popularity in both cognitive linguistics and psychology, the cultural context was not kept in the background. As J. Fodor pointed out, the transmitted information center is censored by the processor and, in turn, is conditioned by culture. And information placed in the cultural model and not recognized does not reach our consciousness, even if it is perceived in our senses. Analyzing the views of J. Fodor, it becomes clear that every transmitted information is censored in our psyche. In accordance with this, J. Fodor puts forward a very interesting principle of "divide and control": "first study the characteristics of all abilities, and then determine their interaction" $[17 ; 1]$. In accordance with this principle, a lot of incoming information is divided into separate fragments, that is, distributed among modules, but even if they are sent for execution, some modules are reduced due to the cultural context. The rest of the information adapts to our cultural knowledge of the world.

Exploring the principle of modularity at the beginning of the XXI century, L. N. Churilin gives a special characteristic to modules, trying to determine the blocks corresponding to conversational activity. In his opinion, each module is specific and has some features:

- Due to the independence of modules the inter-module information exchange is weaker than the internal information exchange;

- Module specification-each module has its own unique functional principle;

- Localization of modules-each module is associated with a specific localization;

- The innate principle of modules-each module has genetic tasks;

- Universality of modules-modules determine the level of syntactic and semantic representation based on this feature [13]. All these modular features are associated with lateralization of the cerebral 
hemispheres. Thanks to this lateralization, the division between the right and left hemispheres of the brain associated with the performance of mental functions is first determined, and then the principles of modular specificity and localization are formed. The formation of functions in every normal person occurs at the age of 14-16 years. The difference in dominant and subdominant functions between the hemispheres up to 12 years remains unnoticed. For this reason, at this age, children do not have a speech defect when the left hemisphere is damaged. A lateralization event in the brain creates an asymmetric functional system between the hemispheres [19].

Interest in brain lateralization has been noticeable since the 1860s. At that time, Paul Brock drew public attention to the facts that he identified with an autopsy after the death of a patient suffering from a speech disorder. Based on these facts, the patient had injuries in the left hemisphere in a different lobe. According to Dr. Brock's findings, speech-related lateralization is located in a distinct part of the left hemisphere. The mechanism of lateralization can also be observed in various types of human behavior in the processes of everyday communication. For example, when calling at the door, people approaching left or right eye to the door point, the person writing right or left hand, people turning up legs at each other in a sitting position, the person performing applause, punch one hand on the other hand that is the dominant's hand, etc. If you think carefully, you can increase this list and identify points that even in our own actions have lateralization. According to the innate lateralization mechanism, which traditionally resembles the letter $X$, the side that makes up the activity is controlled by the hemisphere located in the opposite direction from it. Due to the lateralization mechanism, both hemispheres of the brain have different functions. This difference has been further proven in studies of people with brain damage. For example, the research conducted by the outstanding scientist A.R. Luria is of particular interest. In his book "Traumatic aphasia" (1947), the great scientist describes various aspects associated with speech disorders. During the great Patriotic War, he was engaged in the treatment of people who received brain injuries. One of the images he got from his research was the so-called "Telegraph style". This part of the book reflects the speech of a patient trying to transfer the content of the film: Одесса! Жулик! Туда... Учиться... Море... Эх! Ми-лици-о-нер... Эх! Знаю! Касса! Папиросы! This patient's speech is organized from infinitive sentences consisting of a single word. As a rule, the patient pronounced nouns in the nominative case, and verbs in the infinitive form. Sometimes he also used past phrases that became a whole association. The patient who could not process parts of these words separately, fully retained the general word base. Another patient had a broken vocabulary, and the grammatical sequence was in a normal state. Unlike them, the other patient could not name the letters, although he could pronounce the words without difficulty.

Conclusions. Thanks to such research, the multifunctional base of the brain is literally lay in front of the eyes. The boundary of the modules is inside micro-periodic vessels, which provides a modular metabolic functions of neurons. According to the proven lateralization principle, the structural basis of each module is local connections. According to the research, the module is a multifunctional unit that receives impulses in different parts of the brain, providing ample opportunities for a fine balance of neurons located close to each other in interaction. For example, let's consider a speech mechanism that differs in its activity from other behavioral lateralizations. It is known that the statistics of people who write with the right hand in the world are more than the number of people who write with the left hand. The life activity of people of both types differs from each other in a certain way. The cause of this difference is considered to be the activity of the Cerebral Hemispheres. $\mathrm{X}$ mechanism basically controls the conversation apparatus of people who write with their right hand to the left hemisphere, and the left hemisphere is taken as the main part, but can not interfere with the lateralization of the right hemisphere. Thanks to the activity of the right hand, the left hemisphere, which is constantly active, forms a person's life in the direction of its functions. The activity of very rare left-handed people is associated with the functional course of the right hemisphere. The creative activity of such people is also associated with the activity of the right hemisphere. "Both in a dream and during the time when our brain is engaged in a completely different work are the consequences of the rudeness of the right hemisphere, which makes us plans for the future" [12]. There are a large number of obscure remaining issues in Fodor's central processor-related theory. The claims put forward by the scientist sometimes create the impression of assumptions that are not theoretically evidence. However, this is one of the issues that many researchers have been interested in lately, and the points revealed in each study may be useful for solving problematic issues. 
1. İ.Haqq1 İhsanoğlu. Beynimizin sirləri. Bak1, 2008.

2. Məmmədov A., Məmmədov M. Diskurs təhlilinin koqnitiv perspektivləri. Çaşığlu, 2010.

3. Veysəlli F. Koqnitiv dilçilik. Bakı, Mütərcim, 2016.

4. Борис М. Величовский. Основы психологии познания. Том 1. 2006.

5. Выготский Л.С. Психология. 2000.

6. Коул М. Культурноисторическая психология. Москва, 1997.

7. Калиниченко С.Г., Мотавкин А.Г. Введение в нейрогенетику. Москва, 2000.

8. Лурия А.Р. Травматическая афазия. Москва : Изд. Акад. мед. наук СССР. 1947.

9. Пинкер С. Язык как инстинктм / пер. с анг. Е.В. Кайдановой. Москва, 2004.

10. Попова 3.Д., Стернин И.А. Когнитивная лингвистика. Москва, 2007.

11. Прибрам К. Языки мозга. Москва : Изд. «Прогресс», 1975.

12. Сергеев Б.Ф. Ум хорошо... Москва : «Молодая гвардия», 1984.

13. Чурилина Л.Н. Актуальные проблемы современной лингвистики : учеб. Пособие. Москва : Наука, 2011.

14. Фролова, Ю.Г. Клиническая нейропсихология. Минск : БГУ, 2016.

15. Язык и проблемы знания. Вестник Московского университета. Серия 9. Филология. 1995. № 4. C. 130-157.

16. Dic.academic.ru.

17. Fodor J. The modularity of Mind. Cambridge, MA. 1983.

18. Langacker R. Foundations of Cognitiv Grammar. Vol. 1 : Theoretical Prezequisites. Stanford University Press, 1987.

19. Levy J., Trevarthen C. Metacontrol of hemispheric function in human split-brain patients. J Exp Psvchol (HP\&P) 2:299-312 Reeves AG, Roberts DW, eds. (1995): Epilepsy and the Corpus Callosum 2. New York : Plenum.

20. Marr D. Early processing of visual information. Philosophical Tranzaktionz of the Royal Society of London 275. P. 483-524.

21. Pinker S. and Bloom P. Natural language and Brain Sciences, Cambridge MA: 2002.

\section{ГаДжИСВа М. КОГНІТИВНА СИСТЕМА ТА КОМП'ЮТЕРНА АНАЛОГІЯ}

Коли ви уважно дивитесь на структуру та діяльність сучасних комп'ютерів, на перший погляд ие нагадує людський організм. Кожен із них буквально запрограмований на виконання спещіальних команд. Цю подібність можна спостерігати більше в когнітивній системі людини. Із проведених досліджень відомо, що когнітивна система, що належить кожній здоровій людині, організована з модулів з різними виконавчими властивостями. Кожен модуль незалежний за своєю сферою діяльності. Але тут міжмодульне спілкування вважається особливо важливим. Складна поведінка людини вважається можливою саме завдяки изим зв'язкам. Мова, щьо відображає в певному сенсі ознаки думки, вважається найефективнішим інструментом у иььому напрямку. У зв'язку із циим вчені, які намагаються визначити когнітивну систему людини за допомогою мови, об'єдналися в рамках когнітивної лінгвістики. Співпрачя між мовними та мислительними модулями є найбільш очевидним показником міжмодульного спілкування. I в якій ситуації реалізуються ці зв'язки, незважаючи на численні дослідження, вони все ще вважаються темними для людства. Мова алгоритмічно вважсається вродженою компетентністю з унікальними здібностями, що виконують процеси. Хомський був великим поштовхом до розширення цих досліджень. Концепція універсальної граматики, організована з шести систем, висунутих вченим на основі традииій Н. Хомського у своїх дослідженнях, викликала особливий інтерес в рамках модульних досліджень. Вчений на ім'я Фодор ввів у когнітивну архітектуру популярну модульну концепиію. Принцип модульності, який став частиною термінології когнітивної лінгвістики, є одним з основних елементів інфраструктури мозку. Тут кожна запрограмована підсистема формує поведінку людини у взаємодії з іншими підсистемами. У иій моделі, яка нагадує комп'ютерну систему Дж. Фодора, процес сприйняття та розуміння мови сприймається як модульний процес, а кінцевий результат - як центральний процесор. У иій інфраструктурі мислення також базується на алгоритмічних правилах відповідно до своєї підсистеми. Підтримуючи зв'язок між теорією свідомості та еволюиією, на відміну від Дюс. Фодора, С. Пінкер розглядає роботу свідомості як реальну комп'ютерну систему. У зв'язку із иим у статті порівнюються думки вчених, які підходять до модульної теорії мозку, з різними аспектами та залучаються до аналізу цікаві ідеї. Хоча твердження, висунуті різними дослідниками, часом не досягають теоретичних доказів, у певному сенсі вони викликають ряд иікавих досліджень.

Ключові слова: когнітивна система, пам'ять, універсальна граматика, модульність мозку, нейрон, ментальний словник, ментальна граматика, ліва та права півкулі. 